\title{
A Hidden Pitfall for REDD: Analysis of Power Relation in Participatory Forest Management on Whether It Is an Obstacle or a Reliever on REDD Pathway
}

\author{
Angelingis Akwilini Makatta, ${ }^{1}$ Faustin Peter Maganga, ${ }^{2}$ and Amos Enock Majule ${ }^{2}$ \\ ${ }^{1}$ Ministry of Natural Resources and Tourism, Forestry Training Institute, Arusha, Tanzania \\ ${ }^{2}$ Institute of Resource Assessment, University of Dar es Salaam, Dar es Salaam, Tanzania \\ Correspondence should be addressed to Angelingis Akwilini Makatta; nginaanyangala@gmail.com
}

Received 6 July 2015; Revised 14 October 2015; Accepted 15 October 2015

Academic Editor: Piermaria Corona

Copyright (C) 2015 Angelingis Akwilini Makatta et al. This is an open access article distributed under the Creative Commons Attribution License, which permits unrestricted use, distribution, and reproduction in any medium, provided the original work is properly cited.

\begin{abstract}
Power relation among stakeholders is a key concept in collaborative approaches. This study aims to examine the reality of the acclaimed power sharing in Participatory Forest Management (PFM) and implication of existing power relation to the national REDD+ programme in Tanzania. The study involved a review of PFM policy and legal supporting documents; meta-analysis of previous studies done at two sites known to have succeeded in PFM; and empirical study at Kolo-Hills forests. Methods used include the meta-analysis of existing literature; Household Questionnaire Survey; Focused Group Discussion; and key person unstructured interviews. Results revealed that a large part of the PFM processes involved power struggle instead of power sharing. REDD+ pilot was perceived to have succeeded in improving PFM only in villages where the majority of the community about $70 \%$ experienced higher levels of inclusiveness and power balance with other PFM stakeholders in PFM processes. Power imbalance and power struggle were also noted in the REDD+ project adoption processes. Thus power relations exercised under PFM fall under potential obstacle rather than a reliever to the REDD+ programme. The study recommends reviewing of PFM legal frameworks to strengthen community empowerment for effectiveness of REDD+ on PFM platform.
\end{abstract}

\section{Introduction}

The role of forest communities as the main stakeholder in forest resource management programmes for pursuing biodiversity conservation and socioeconomic objectives has been extensively announced in recent decades [1-4]. Various terms have been used in different countries to express delegation of power to lowest level of community to manage natural resources proximately. In Tanzania Participatory Forest Management (PFM) is an approach involving multiple stakeholders in decision making over resources management, which is characterized by the transfer of power from central (state authority) and structures to lower levels (village authorities). PFM can be conceived as community empowerment to manage forest resources $[5,6]$. Central to the approach is sharing of power among the stakeholders towards predetermined common objectives at global, national, and local levels [6-8]. It represents a paradigmatic shift in natural resources governance ideology from "fortress" state-centred protectionist conservation to "inclusive" people-centred conservation approaches. Power relation among stakeholders is a key concept for an understanding of status of collaborative approaches to natural resources management including Participatory Forest Resource Management. Power relation is among basic determinant factors for success or failure of participatory natural resource governance approaches [9-11]. Recent experience from China shows that where collaborative approaches are adopted on papers while decisive power is retained by central government the outcomes have been an accelerated degradation of resources and biodiversity loss contrary to expected outcome of improved management and biodiversity conservation $[12,13]$. Study elsewhere in Tanzania by Vihemäki [14] expresses power relationships between state and community actors as a shaping agent to PFM as well as a resultant product shaped by PFM approaches. 
Since PFM approaches are given prime consideration in strategies for pursuing goals of various multilateral environmental treaties including the UN Framework Convention on Climate Change (UNFCCC), it is indispensable to scrutinize how power relations can help to explain the processes and outcomes of PFM and REDD+ initiatives.

The term "power" has diverse definition, but all meant to describe the ability of a person or a group of people to influence and control the behaviour of others in the direction that is against their will. According to Giddens $[15,16]$, power is defined as a capacity of agents to achieve outcomes in social practices. Lukes [17] regards power as the ability to inspire people's minds interests that are contrary to their own good.

Power resource refers to particular attribute(s) that an actor is embedded in or holds, which endow him/her with potential to influence and achieve his/her determination. Communities involved in PFM need power to both exclude other users and also regulate utilization so that resources can be used sustainably.

According to Benjaminsen and Svarstad [18] there are several forms of power resources including economic power resource, legal rights to land and natural resources, political influence power resource, influence on governmental institutions, discursive power resource, knowledge power resource, "weapon of the weak," and identity power resource. Barnett and Duvall [19] and also Nuijten [9] summarize power from all those power resources into three main categories of strategic power, institutional power, and structural power. Power operates in actors and institutions whereby actors use one or multiple forms of power resources [18].

Power relation in this paper refers to ways in which actors and institutions have exercised power from their power resources in PFM processes from introduction, implementation, and distribution of benefits. Actors involved in PFM processes include central government forest agency officials; district council authorities; donor agencies officials; politicians and village communities through their Village Natural Resources Committees (VNRCs) or Village Forest Management Committees (VFCs). Institutions refer to policy and legal tools in support of PFM including National Forest Policy [20]; Forest Act number 14 [21]; Local Authorities Act number 7 [22]; Land Act 1999 number 4 [23]; and Village Land Act number 5 [24].

The objective of this paper is to examine power relation's potential to influence outcomes of PFM and the implication to REDD+ programme in Tanzania. This paper was intended to ascertain main kind of power relations exercised amongst PFM key stakeholders in striving to achieve their interests.

\section{Materials and Methods}

\subsection{Meta-Analysis of Existing Literature}

2.1.1. Power Relation Exercised by the Government Actors and Institutions in PFM Processes. In the late 1990s Tanzania like many other countries of developing world adopted decentralization of forest resources governance approaches collectively referred to as Participatory Forest Management (PFM) as a sturdy effort towards achievement of sustainable forest management at reduced cost. This was executed through radical institutional reforms in the forest sector including formulation Forest Policy of 1998 followed by the enactment of Forest Act of 2002 and forest legislation. Other tools for implementation of the policy were the National Forest Programme (NFP) (2001 to 2010) that provided a strategic framework for implementation of forest sector policy and reinforce the role of stakeholders from the public and private sectors. Also Community Based Forest Management Guidelines are issued by MNRT in 2001 to display step-by-step procedures for CBFM establishment and finally the Forest Regulations of 2004 to operationalize the Forest Act of 2002. All these institutions aimed towards fast and effective transfer of management responsibilities to communities' lowest level of governance unity. This simply means only transferring forest resources management burdens rather than benefits to the local level.

To ensure the attainment of community low cost forest management without compromising government central control over the resources, power transferred to community was limited to enable them to serve interests of the government on conservation and not their livelihood interests [25]. The approaches to involve communities in forest management were set strategically in such a way that they look very attractive to community and also to donors for financial and logistics support. Community empowerment and livelihood benefits for poverty alleviation were put at front in PFM promotion as dual objectives of the approaches but when it came to implementation livelihood benefits were the spinoff of community conservation efforts. Bullock [26] noted that PFM was trademarked by devolving village autonomy in benefit sharing and revenue management. The livelihood benefits reported at PFM sites include access of clean water as a result of increased water flow from water sources and in rare cases increase in access of nontimber products like wild fruits. Due to power imbalance between the forest owner (government) and the managing collaborator (communities), the former has used its power to exploit the latter in terms of energy and time for about 20 years of JFM implementation while keeping silence on unclear benefit sharing terms [27].

The trick of the government to restrict devolution of substantial power to community can be noted in the limited provisions of the Forest Policy and the Forest Act. The National Forest Policy [20] while it is encouraging forest adjacent communities to engage in forest management responsibilities with local and central government forest reserves for reward of appropriate user rights does not state who is provider of working resources to communities. The policy is silent on the role of government forest agency: Tanzania Forest Service Agency (TFS) and other government institutions on the management of central government forest reserves under Joint Forest Management (JFM). Likewise the policy does not recognize the village as a key community institution for JFM but recognizes an organized community (Policy Statement 3 (p.17)), while in actual practice JFM is permitted by signing agreement for comanagement between village leaders and government forest agency officials. The policy strongly encourages devolution of management responsibilities of unreserved forests to village governments as a means to 
improve management but silent on devolving financial and material resources for the same. According to Agrawal and Ostrom [28] rights and capacities that are transferred to actors at lower levels are the major determinants of the outcomes of devolution approaches to forestry resources management. The forest legislation provides a clear legal procedure for assertion and gazettement of Village Land Forests including Village Forest reserves, Community Forest Reserves, and private forest reserves. However, the Forest Policy, Forest Act, and legislation are silent on degazettement and degazettement procedures of Village Land Forest Reserves when in future the village communities need to utilize the land for alternative social and economic investments.

The Forest Policy and Forest Act legalized JFM as comanagement approach involving the community (invited partner in management) and government (the forest owner). It requires management responsibilities to be handled to communities but it is keeping silence on sharing of economic gains from the forests and also on practical management activities/responsibilities of the government part. Similarly the government has been infringing its own approved Forest Act because the Forest Policy and Forest Act require signing of Joint Management Agreement (JMA) as a prerequisite for comanagement to be implemented but in most cases JFM has been implemented without approval of JMA by government part. The government has been reluctant in signing JMA particularly those relating to JFM in productive National Forest Reserves (NFRs). Only a few number of agreements have been signed by the government out of several hundred villages developed JMAs around a range of forests managed by central or local government for more than two decades. Furthermore, power of communities to hold the government or the government forest agency accountable in case of violation of the JMA is barred.

Although the Forest Act [21] gives power to village communities to reserve and gazette Village Land Forest Reserves (VLFRs) on village land, communities can only gain the power when the village is registered and has a Certificate of Village Land [24]. The registration conditionality limits power to unregistered majority of villages in Tanzania. Conversely those villages may have limited opportunity to benefit from Community Based Forest Management (CBFM) and REDD+ programme carbon credits.

Likewise although Forest Act [21] provisions seem to empower communities with full ownership and management responsibility under CBFM regime, the same Act gives power to the Director of Forestry or local governments to take over the management of forests that are under CBFM or JFM if the forests are deemed to be mismanaged [21]. This creates unsecured community access and user rights to forest resources under CBFM and JFM regimes.

The greediness of the government to continue holding ultimate power over the resources was found to be the pivotal barrier to PFM effectiveness, yet it was deemed to escalate in REDD+ implementation [29, 30].

2.1.2. Power Relation Exercised by the Community under $P F M$. In the beginning of PFM community readily accepted the seemingly offered opportunity of being empowered to manage forest resources. The community gladly accepted the approach because it was their desire to gain back control over the resources they enjoyed before but lost under the colonial government with the establishment of centralised resources governance. They were also in need of fulfilling their livelihood demands from the forest resources.

The first PFM evaluation report [31] revealed that communities under PFM gained power over the resources and effectively excluded the outsiders from unsustainable use of the resources. Consequently, within few years of PFM implementation, degraded forests were reported to recover through regeneration, wild animals that disappeared from degraded forests had returned to the forests, and streams originating from PFM forests were reported to have increased water flow while incidences of illegal activities in those forests were seldom. All these were evidences for positive outcomes of PFM on conservation. However the same report disclosed that the outcome of PFM on improved livelihood of participating communities was negligible.

Thereafter, government efforts were directed toward scaling up of PFM throughout the country. The second evaluation report [27] three years after the first report had nothing new from the former other than increased area coverage in terms of number of hectares, villages, and districts involved in PFM. However ever since, nothing has been reported on the performance quality of PFM in early adopted sites. This makes the reality of PFM performance quality remain gloomy. For those who are keen to visualize through the "window of the government practices" they can see the reality. The tendency of government surveillance team to conduct frequent and sudden forest protection patrols in JFM forests has been seen as a way of recentralizing while decentralizing on the management of forest resources owned by the government. This has been necessary attempts of the government to contain accelerated exploitation on protective forest reserves under JFM. Though it is not publically declared, the government has noticed that the communities' tolerance has ended and the community had employed "weapon of the weak" power whereby silently they exploited the forest resources as compensation to their management efforts. The Village Forest Natural Resources/Village Forest Management Committees (VNRCs/VFCs) used to oversee controlled utilization of forest resources for sustainability turned to be promoters of exploitation and informers to the community to alert them to the strategies of forest agency to contain escalated exploitation of resources by communities.

Through personal communication to several forest managers of PFM forests concerning current performance of PFM in controlling deforestation and forest degradation, they all said the approach was very ambitious and unworkable. They said instead of containing illegal activities, it has worsened it. They mentioned the reason for the situation now getting worse than before JFM is that with PFM community has been exposed to resources and knows the stock of the forest at every point. Also they are very aware of the resources and manpower capability of the district forest departments on containing their planned crime over the forests. Therefore communities are sure of their security while doing illegal exploitation of timber resources on protected forests. For 
instance, on 22 March 2015, I visited Monduli district catchment forests office and I did witness about $5 \mathrm{M}^{3}$ of stacked wood outside the office. The district catchment manager informed that the wood was obtained from a single day patrol in the forest conducted without informing the community by staff from her office in collaboration with staff from wildlife department (personal communication). This is similar to the findings from study elsewhere in Tanzania by Brockington [32] suggesting that "village forest management committee are not functioning well and forests are not well protected". Similar experience has happened in China whereby the protected areas built under the Grain for Green Project (GGP) conservation programme were at risk of undergoing greater levels of damage by local residents because of dissatisfaction of the communities with little conservation cost which is compensation from the central government [13].

2.1.3. Power Relation Experienced at Two Renowned PFM Success Sites of Angai and SULEDO Forests. Analysis of existing literature at two popular sites of Angai and SULEDO known to have succeeded PFM revealed various power relationships that were exercised by different stakeholders in the course of establishing and implementing PFM at these sites.

For Angai, PFM process involved sort of power struggle among three actors/stakeholders: local government of Liwale district authority and community in villages that border the forest and Finnish Funded Rural Integrated Programme Support (RIPS) NGO. Government used its institutional as well as structural power in trying to influence gazettement of Angai forests as a Local Government Forest Reserve (LGFR) instead of Village Land Forest Reserve (VLFR). RIPS with its structural and financial power was able to break through its interest of involving 13 villages adjacent to forests and thus changed the targeted forest ownership from district council to community forest. The district authority silently disagreed with the establishment of Community Forest Reserve; hence it used its institutional power to delay processes for establishing the AVLRF for about six years [33]. Under strong push by institutional and financial power of RIPS, being backed by the Forest Policy the establishment of AVLRF was realized [33]. This was followed by the process to issue a Village Land Certificate to each respective village government. This is because while Land Act [23] recognizes customary rights of occupancy even if the land is not registered and the landholder has no certificate, Village Land Act [24] recognizes village land right of occupancy on registered village, attested by certificate of registration. The certificate renders villages with power to control and excluding others from the resources. Again this took more than seven years. However, even after having the certificate, communities' power to utilize forest resources for livelihoods was still constrained by the institutional power of district authority granted under the local government Act number 7 [22]; Forest Policy [20]; and Forest Act [21] to approve community proposal for extractive utilization of timber resources only after having a detailed forest management plan. Preparation of the management plant was highly technical and financially demanding for village communities to afford, and thus it took again two years to accomplish the work after securing financial support from Finnish development cooperation through Tanzanian National Forest Programme (NFP).

The accomplishment of AVLRF management plan raised hope for communities to start utilizing timber resources as fruits of their management efforts after 15 years. On the contrary higher government power tiers had identified Angai forests among sites for pilot REDD+ project which is against exploitation of timber products and instead expecting to award community for being more restrictive on harvesting so as to accumulate more carbon stock [29]. Due to complexity in REDD+ implementation process, guarantee of community rewards through REDD+ cobenefits seems to be uncertain [30].

For the case of SULEDO forests, historically the area has been occupied by Maasai tribe and recognised as special area for pastoral activities since back to colonial era. The central government in 1983 with its institutional power decided to change status of the area and exclude the Maasai community by turning the area into a proposed forest reserve [34]. Due to strong strategic power of Maasai society it was not easy for the government to gazette the forests without support from the community. However community in nine villages used their institutional power rendered to them through the Forest Act to maintain control of the resources by gazetting the forest as Community Forest Reserve. Institutional power gained by the communities at SULEDO forests excluded outsiders from the right to directly access and benefit from the resources [35] including the district authority. Having lost direct control over the income from forests at SULEDO, Kiteto district authority using institutional, structural, and financial power silently strives to fail community efforts through delaying processes for timber harvesting proposed by village councils and limiting facilitation to district forest officer who is responsible for assisting communities forest management technical issues [34]. According to [33], potential revenue from sustainable timber harvesting at community managed forests amounts to USD 15,000 and USD 70,000 USD per village per year for SULEDO and Angai VLFRS forests, respectively. Based on this fact, the government recommended that the harvesting of timber is to be dealt by a private sector operator through lease or tender arrangements, for the reason that such amount of revenue is too huge for village governments to handle. Clearly this seems to be an attempt of using knowledge as power to snatch the revenue from control of the community. One could question why the recommendation was not focusing on building capacity of village governments regarding financial management.

The community using "weapon of the weak" power silently decline participation in forest management activities as a result of discouragement from district authority. This created a loophole for corrupt village leaders to use structural power and few elites with strong strategic power to grab most of opportunities from PFM including appropriation of income collected from the forests (elite capture) [34]. Similar to Angai situation, the dream of SULEDO communities to benefit from commercial timber harvesting has been diminishing with the introduction of REDD+ initiatives spearheaded by national and international conservation super powers. 


\subsection{Empirical Study on Power Relation under PFM at Kolo-Hills at Forests}

2.2.1. Location of the Study Area. This study was conducted as part of big research project under Climate Change Impacts, Adaptation and Mitigation Programme Tanzania (CCIAM). The study site is found in Kondoa district located between latitudes $4^{\circ} 10^{\prime}-5^{\circ} 44^{\prime}$ south and longitudes $34^{\circ} 54^{\prime}-36^{\circ} 28^{\prime}$ east, in Dodoma region of central Tanzania $[36,37]$. The district climate condition is semiarid with minimum and maximum temperature of $16^{\circ} \mathrm{C}$ and $29^{\circ} \mathrm{C}$, respectively, while annual rainfall ranges between 500 and $800 \mathrm{~mm}$ [36-38].

The study was based at Kolo-Hills forests commonly known as Isabe and Salanga forest reserves and the surrounding village of Mnenia, Masawi, Humai, Kisese-Disa, and Kikore. Selection of Kolo-Hills site is based on having experience of both PFM and also a REDD+ pilot project. The forest reserves are found $30 \mathrm{~km}$ east-south of Kondoa district council township and cover about $346 \mathrm{~km}^{2}$. The villages and the forest are located at $4^{\circ} 54^{\prime} 983^{\prime \prime} \mathrm{S}$ and $35^{\circ} 47^{\prime} 937^{\prime \prime} \mathrm{E}$ at elevation of range between 1650 and $2000 \mathrm{M}$ above the sea level [39].

2.2.2. Research Design. Household survey was conducted to 250 household heads randomly selected from five villages with disproportionate sampling whereby 50 households from each village were selected from village registers with an aid of random numbers generated using a computer. Sampling unit was a household, defined as all members related and unrelated who share the same dwelling unit or a group of people sharing resources, expenditures, and responsibilities [40]. Apart from the household survey, key person unstructured interviews were conducted.

Key persons were 2 village leaders (chairperson and village executive officer) of each village, and some elders in the community; two district authority forest officers; the district land, natural resources, and environmental officer; and two staff members from Wildlife Foundation (AWF) which is responsible for implementation of REDD+ pilot named ARKFor at Kolo-Hills forests. Again researchers' observation was used alongside household survey to observe social setting and daily community interaction with forest resources proximately. The use of several methods in data collection is a triangulation technique to reduce error due bias that may occur in data collection and thus increase reliability of the data [41]. Questionnaires and checklists of questions are survey tools used for data collection. Both questionnaires and checklists were prepared in English and Kiswahili and administered in Kiswahili (the national language in Tanzania) by the authors. Kiswahili language is fluently spoken by the study communities apart from their mother tongue.

Response to questions was measured using rank of points which correspond to the respondent's perceived level of performance using a five-point Likert scale. Respondents were asked to indicate values which reflected level of agreement with a statement $(0=$ strongly disagree, $4=$ strongly agree $)$ or a rating of the frequency of occurrence of an event or behaviour $(0=$ not at all, $4=$ always $)$. A high score indicated a greater agreeing or higher frequency of an event occurrence or level of performance.
The data was collected from communities of 5 villages: Mnenia, Humai, Masawi, Kisese-Disa, and Kikore (indicated by yellow dots in Figure 1).

Exploration as well as analysis of the data from household survey was done using SPSS Version 16 and Microsoft Excel Office 2007 computer programmes. Content and StructuralFunctional Analysis technique was applied to summarize text information from key person unstructured interview into meaningful statements presented in results.

\section{Results and Discussions}

\subsection{Results}

3.1.1. Results from Unstructured Interviews. Unstructured key persons interviews conducted to two staff members from Kondoa district forest department revealed intense use of coercive power over communities who resisted adoption of REDD+ pilot project at their forest area. Box 1 includes the information which was given under condition that their names will be kept anonymous for their job security.

Local government at district authority strives to maintain control over forest resources which are under comanagement with communities through institutional power. Lack of inclusiveness and clarity of REDD+ pilot project objectives created doubt on security of communities' access rights to forest resources; thus some villages refused to adopt it. Among the villages resisting REDD+ pilot project is Kisese-Disa. Following their resistance, local authority government of Kondoa district council used various kinds of its power to force the acceptance of the project.

Based on the Local Authorities Act number 7 of 1982 village governments are subordinated to district councils. Thus village governments depend on district council's goodwill when it comes to approval of community decisions as well as social and economic welfare support. Consequently the government of Kondoa district restricted supply of social and economic services to those villages resisting REDD+ pilot project as an instrument to threaten them to accept the project.

The existence of resistance towards the REDD+ pilot project at Kolo-Hills by some villages was also mentioned in the Mid-Term Review Report of the project but according to the report, the resistance was mitigated through engaging large numbers of community members in project activities and creating patrols that are made up of members from multiple villages. The study revealed contradicting reasons for the resistance. While the Mid-Term Review Report mentioned personal interests of some village leaders who benefitted from deforestation activities as the reason, information from interview with common people of the community disclosed that resistance to REDD+ pilot project was due to fear of losing access to daily needs from the forest and fear of imposition of severe punishment as opposed to those locally agreed in by-laws concerning violation of forest management and utilization rules. They said community viewed REDD+ project as a strategy to extend Tarangire National Park to include Kolo-Hills forests which would lead to wildlife-community conflicts as it happened in various 


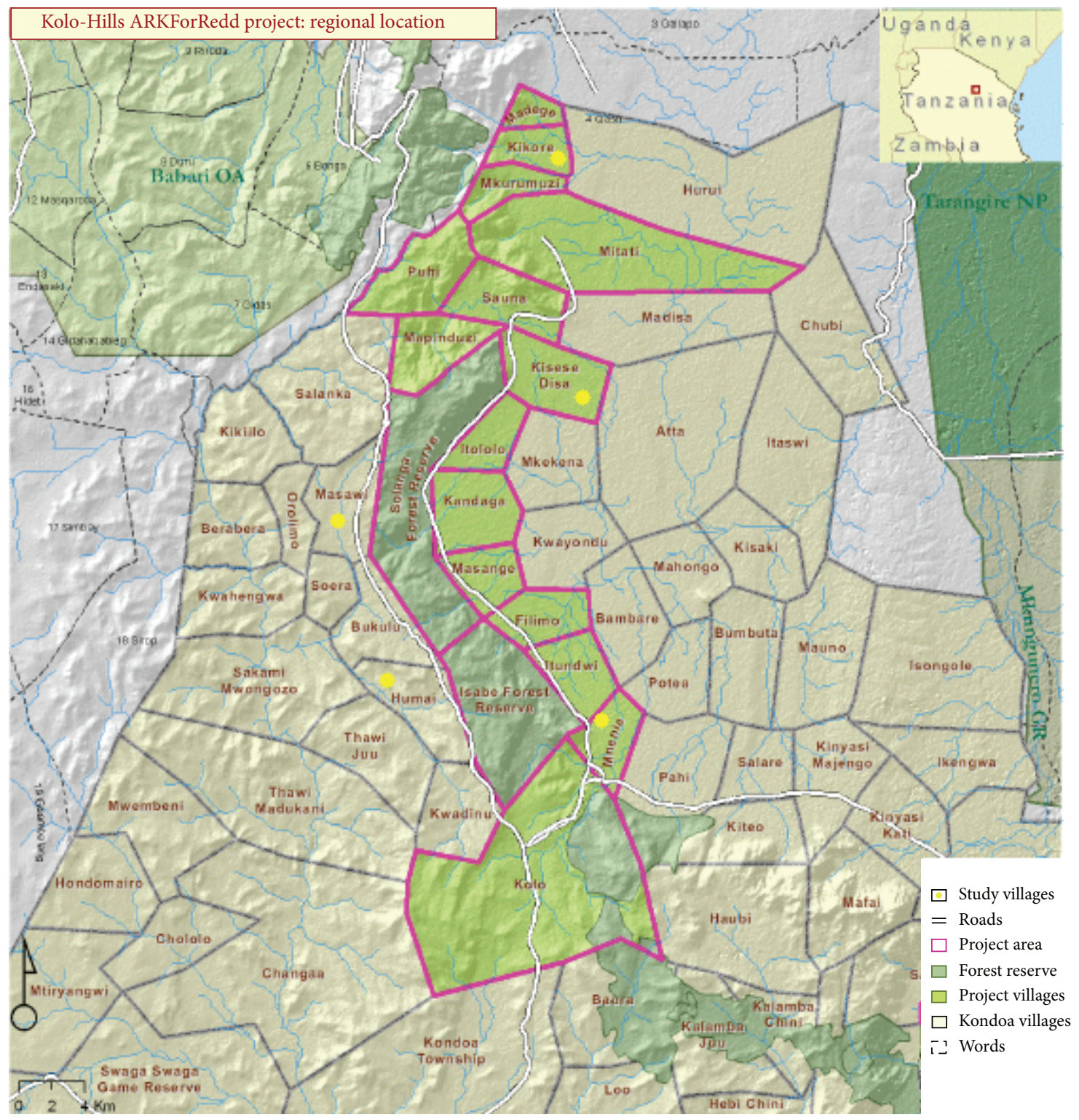

(Source: ARKFor feasibility study report 2010).

FIGURE 1: Map of the study area showing ARKFor REDD+ pilot and CCIAM project area and study villages.

parts of the country. The interviewees insisted that resistance to REDD+ project was based on aforementioned reasons that were enfolded by inadequate information (clarity) about the project but not grounded on political influence as mentioned by project leaders.

Information from unstructured interview with staff from AWF and Kondoa district about number of villages involved in PFM and REDD+ pilot project was contradicting. While AWF staff informing that all 21 villages have agreed to participate and are involved in the project, the district land and natural resources management officer informed that there are villages that resisted the project and are not participating in the project activities, and one of the villages is Kisese-Disa. The conflicting information seems to be an attempt of AWF to mask their ineffectiveness in REDD+ pilot implementation by overrating the success including area coverage in terms of villages involved.

The explanation from the three villages (Boxes 2-4) discloses prevalence of community dissatisfaction on power imbalance among the government at district council and village communities as copartners of forest management under PFM. Additionally the community complains about the little incentives from PFM due to many restrictions on taking products from the forest.

3.1.2. Results from Household Questionnaire Survey. About $60 \%$ of all respondents $(n=250)$ from five villages ranked preparation time for adoption of PFM and REDD+ initiatives; 
They said "there are some villages that willingly accepted PFM and REDD+ pilot while others resisted REDD+ project. In Kisese-Disa village the resistance was very strong because of political influence from their Parliamentary representative member. At first instant a team for REDD+ promoters at Kolo Hills called an audience with district administrative staff of different fields including the parliamentary representative member and explained their plan to implement REDD+ pilot project at Kolo-Hills forests. Their proposal was agreed after putting clear the project objectives and the overall framework for implementation that would involve villages bordering the forests. The meeting participants agreed to encourage people to adopt the project for their economic benefit from anticipated carbon credit for conserving the forests. Contrarily that Member of Parliament went back to Kisese-Disa village and start advocating hateful issues attributed to REDD+ pilot project and the promoters. For that reason this village resisted REDD+ at their village forest management area.

However REDD+ project administration in collaboration with Kondoa district authority forced this village to accept and collaborate with other villages in REDD+ project forest management activities including sending representatives to joint forest guard team. This team is directly accountable to REDD+ pilot project and it is responsible to ensure protection of overall forests at Kolo Hills. Though Kisese-Disa village maintained their resistance to the REDD+ project, the forest guard team composed of members from all villages persistently conduct patrol over the whole forest area under REDD+ pilot including forest areas of villages who refused the project.

Kisese-Disa village wanted to show their disagreement to those who conduct patrol activities at their forest area and some youngsters of the village were sent by elders to kidnap one of female forest guard member of the joint team while the team was patrolling at Kisese-Disa forest area. The rest of the team conveyed the kidnapping information to REDD+ project administration (AWF) and Kondoa district. Immediate support from Kondoa district including the two of us and armed professional guards from TARANGIRE National park sent by AWF arrived at the event site and start to search for the guard who was kidnapped. Following that, the Kisese-Disa youngsters immediately decided to release the guard safely to the forest. When the team tried to communicate to her, she told them she was free and safe.

However the team continued to search for the kidnap suspects up to the evening. Around 8:00pm the armed Tanzania National Parks (TANAPA) guards from Tarangire National Park together with us started to ambush the suspects in their home dwellings, forcing whoever found there to hand the suspects. We managed to catch few suspects and TANAPA staff taught them a lesson. They commanded them to do severe physical exercises to the extent that some suspects released bowel materials to their clothes unconsciously. Noticing that after taking them onto their truck, the TANAPA guards ordered them to drop out of the truck and wash it thoroughly and after that they released them without any court case proceeding on the matter".

Explaining more on the set strategies to force the village to accept REDD+, they said "we believe it will reach a point where the troublesome villages will surrender and accept the project since there is a planned persistent silent punishment of isolating and neglecting them from various social and economic development support from the district. For instance currently Kisese-Disa village is obliged to participate in protection of Kolo-Hills forests in collaboration with other villages but it is excluded from beneficiaries of carbon credit and other economic incentives expected to come through REDD+ programme and PFM".

Box 1: Unstructured interview conducted with two staff members from Kondoa district responsible for the management of Kolo-Hills forests.

power balance among stakeholders; and good understanding (clarity) about the initiatives below average scores. This implies that the three factors are areas of weakness which are potential barrier for effectiveness of both PFM and REDD+ initiatives. Of the three factors, power balance was ranked as the most weakly exercised. Through ANOVA statistical test, significant difference of scores between villages was revealed at $p<0.05$. About $70 \%$ of respondents from Mnenia and Kikore rated the three factors as good performance while more than $80 \%$ of respondents from Kisese-Disa and Masawi villages ranked the three factors below average scores which implies poor performance (Figure 2).

However, PFM success after REED+ project seems to be more pronounced in villages that experienced higher levels of power balance among stakeholders; good understanding (clarity) about the initiatives; and adequate preparation time for adoption of PFM and REDD+. For instance, Mnenia village which scores higher in all three factors had highest perceived PFM success.

Table 1 displays some REDD+ challenges and opportunities experienced by the community at Kolo-Hills including increased restrictions over forest resources after REDD+ pilot and additional benefits. However for those villages that experienced high level of power imbalance they also experienced high level of additional restrictions with little or no additional benefits from REDD+ pilot project.

3.2. Discussion. Although from the literature Tanzania has been commended for being at the forefront in refined laws for people-centred rather than state-centred in power holding in natural resources management issues, this has been rhetoric while the reverse seems to be reality. This can be verified from 
He said "In the beginning, we agreed to work with district council forest staff as they said the government has decided to give back the forests to local people to protect them and collect our needs from the forest like firewood. We were asked to formulate Village forest management Committee which would work with the district people on behalf of the community in protecting the forest. We were asked to plan the way of using the forests without destroying them and we did. The problem is that thereafter there was misunderstanding among village government (village council) leaders and that forest management committee. The whole village leadership collapsed and we elected new village government. Therefore, all forest management arrangements ended with the previous village leadership. However we continued to protect our forests and get our needs there until when district people wanted to give the forest to African Wildlife Foundation (AWF) with the name of REDD+ project. We refused to work with AWF because they are Tarangire National Park people. It is hard to believe TANAPA people you know! They can take our forest as they did to other places we heard in Arusha and Kilimanjaro regions. Although we refused to work with AWF as our partners, they forced us to accept REDD+ project and have imposed many restrictions on the forests. To date if we enter the forest we get caught by a team of forest guards of AWF trained from every village and sometimes with park rangers of Tarangire national Park who join district people in patrolling the forest. When youngsters are caught cutting poles for repairing or constructing a house they are beaten hardly without taking them to court, which is against the Forest Act and our village by-laws".

Box 2: Unstructured interview with one of key persons from Kisese-Disa village (a village leader). How can you comment on the status of PFM and REDD at your village?

"What REDD+ project people are doing is not constructive at all! Before the project we had established effective system for protecting forests under Community Based Forest Management (CBFM). It is well know that village government has authority as a manager and owner of VLFRs on behalf of the community. It is the one which is responsible to ensure forests are well managed based on the village forest management plan document. Surprisingly, REDD+ pilot project came and re-establish new institution which is joint team of forest guards that is over the village government and directly answerable to them. You can imagine how awkward it is; a group of individuals from different villages mealy selected randomly are given power to collect fines from forest defaulters without consultation of village government leaders of the particular forest area. Nobody knows at village what is happening on the forest because at village office nowadays there has been no either a report of patrols performance, offences or that of defaulters and action taken over them. Because forest patrols are done at forest landscape wide not village based; there have been cases where fine for a crime done at a certain village is collected at another village. This is a kind of overthrowing the village government from its legal authority".

Box 3: Unstructured interview with one of key persons from Kikore who is a member of village standing committees.

\footnotetext{
"In average PFM approach is going well, except for the issue of benefits to community. It is very annoying because we as the partners to the government we forego our productive activities and attend meetings to discuss issues of forests, we do patrolling activities and all about the wellbeing of the forest but we are always restricted of many things. We agreed to not graze in the forest because cows may destroy small trees. We are happy to have good forest around us and wishing to maintain them unspoiled for our grannies. However we maintain living trees and not dead ones! Why government restricts us to take dead trees for our use? They say we are allowed to gather fire wood but we should go into the forest empty handed without cutting tools. How is it possible to take whole dead trees without tools? There are lots of big timber trees which have died under natural causes. Here we have our primary school that is under shortage of desks and even firewood for preparing lunch for pupils. The dead trees could be used to solve some of school demands. The village government asked the district forest officer to come to verify and oversee the process of removing those dead logs from the forest but for months they didn't even turn up".
}

Box 4: Unstructured interview with one of key persons from Masawi village providing a view about PFM and REDD+ pilot project situation. 
TABLE 1: Experienced additional restrictions and benefits on forests after REDD+ pilot project.

\begin{tabular}{|c|c|c|c|c|c|c|c|c|c|c|}
\hline & \multicolumn{10}{|c|}{ Villages } \\
\hline & Mnenia & Freq & Masawi & Freq & Humai & Freq & Kisese-Disa & Freq & Kikore & Freq \\
\hline \multicolumn{11}{|c|}{ Additional restrictions from REDD+ } \\
\hline Tree cut for construction & $\sqrt{ }$ & 10 & $\sqrt{ }$ & 13 & $\sqrt{ }$ & 13 & $\sqrt{ }$ & 15 & $\sqrt{ }$ & 20 \\
\hline Entrance (short cut foot path) & $\sqrt{ }$ & 9 & $\sqrt{ }$ & 9 & $\sqrt{ }$ & 3 & $\sqrt{ }$ & 22 & $\sqrt{ }$ & 12 \\
\hline Firewood collection & $\sqrt{ }$ & 6 & $\sqrt{ }$ & 8 & $\sqrt{ }$ & 2 & $\sqrt{ }$ & 1 & $\sqrt{ }$ & 0 \\
\hline Grazing & $\sqrt{ }$ & 7 & $\sqrt{ }$ & 15 & $\sqrt{ }$ & 9 & $\sqrt{ }$ & 22 & $\sqrt{ }$ & 18 \\
\hline No restriction & $\sqrt{ }$ & 6 & $\sqrt{ }$ & 3 & $\sqrt{ }$ & 5 & $\mathrm{x}$ & 0 & $\sqrt{ }$ & 7 \\
\hline Agriculture farming & $\sqrt{ }$ & 2 & $\sqrt{ }$ & 2 & $\mathrm{x}$ & 0 & $\mathrm{x}$ & 0 & $\sqrt{ }$ & 9 \\
\hline Sum & & 34 & & 47 & & 27 & & 60 & & 59 \\
\hline \multicolumn{11}{|l|}{ Additional benefits from REDD+ } \\
\hline Income from IGAs & $\sqrt{ }$ & 16 & $\sqrt{ }$ & 4 & $\sqrt{ }$ & 2 & $\mathrm{x}$ & 0 & $\sqrt{ }$ & 10 \\
\hline Ecological services & $\sqrt{ }$ & 17 & $\sqrt{ }$ & 4 & $\sqrt{ }$ & 9 & $\mathrm{x}$ & 0 & $\sqrt{ }$ & 11 \\
\hline Improved farming & $\sqrt{ }$ & 3 & $\sqrt{ }$ & 2 & $\sqrt{ }$ & 3 & $\mathrm{x}$ & 0 & $\sqrt{ }$ & 5 \\
\hline No additional benefit & $\sqrt{ }$ & 2 & $\sqrt{ }$ & 24 & $\sqrt{ }$ & 11 & $\sqrt{ }$ & 30 & $\sqrt{ }$ & 10 \\
\hline CO trial payment & $\sqrt{ }$ & 25 & $\sqrt{ }$ & 18 & $\sqrt{ }$ & 7 & $\mathrm{x}$ & 0 & $\sqrt{ }$ & 15 \\
\hline Extension education & $\sqrt{ }$ & 16 & $\mathrm{x}$ & 0 & $\sqrt{ }$ & 5 & $\mathrm{x}$ & 0 & $\sqrt{ }$ & 4 \\
\hline Forest products & $\sqrt{ }$ & 5 & $\mathrm{x}$ & 0 & $\mathrm{x}$ & 0 & $\mathrm{x}$ & 0 & $\sqrt{ }$ & 13 \\
\hline Sum & & 82 & & 28 & & 26 & & $\mathbf{0}$ & & 58 \\
\hline
\end{tabular}

Freq: frequency of the item was mentioned.

$\sqrt{ }$ : item was mentioned.

$\mathrm{x}$ : item was not mentioned.

Note: assumption under the table displays that the more frequent an item was mentioned, the more it benefits or costs the community.

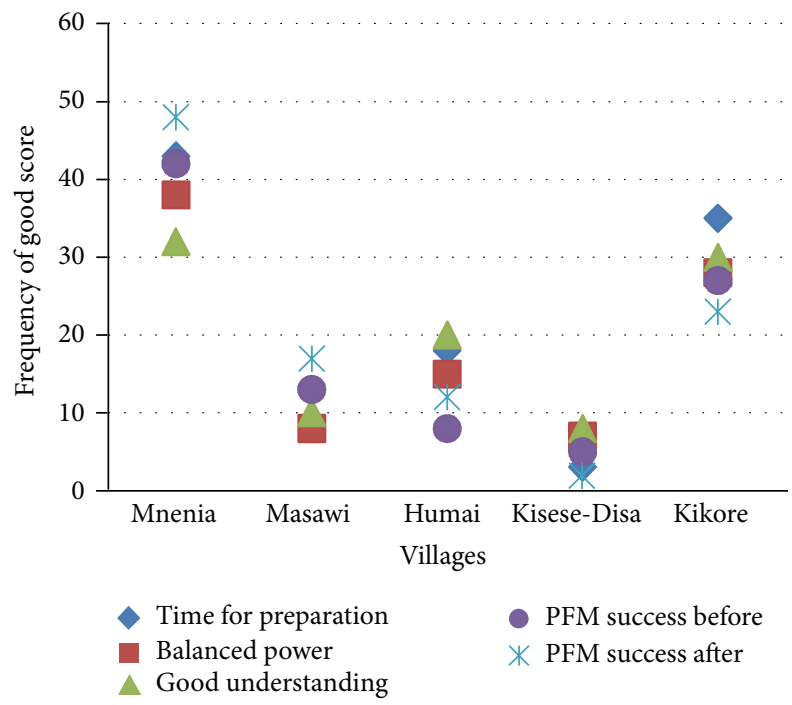

FIGURE 2: Comparison of perceived success of PFM before REDD+ and with REDD+ pilot project under different status of time for preparation; balanced power; good understanding of the programmes.

initial national programme to support PFM implementation with the goal "natural resources contributed on sustainable basis towards reduced income poverty, vulnerability amongst the poorest groups and improved quality of life and social well-being in Tanzania" and objective to "increased benefits to rural communities based on sustainable natural resource management in Tanzania." The programme which was known as the Management of Natural Resources Programme was implemented with financial support of the Government of Norway for about 13 years from 1994 to 2006 when it was phased out with negligible impact on PFM contribution to local communities' livelihood. The reason explained was that livelihood centred objective was theoretical for donor's aid focus but when it came to implementation the efforts and utilization of funds were concentrated towards conservation while ignoring support to community livelihood [42].

The prevailing PFM circumstances whereby the government has delegated responsibility to people while it retains facilities and financial resources for implementation can be viewed as a kind of exploitation which opposes power sharing. Similarly study elsewhere by Mustalahti [33] commented that "participatory and decentralised forest management can hardly guarantee rights of the local people particularly in a situation where devolution and transfer of power to community level governing board (Village for Tanzania) without transferring financial, material and technical resources necessary for local government to fulfil its obligations, such kind of empowerment is meaningless." Also "if central governments grant local governments the rights to make and implement decisions but in practice withhold resources or otherwise check local ability to do so, then discretionary powers have not been effectively transferred" [43]. The oppressive situation in some PFM communities where people are forced to adopt new management arrangement at their PFM managed forests as found at Kisese-Disa village in this study is contrary to power sharing. People have been distressed for the sake of project REDD+ project administration to display illusive success on paper with justification that all 21 
villages have accepted and implemented the project. In fact, on these grounds REDD+ pilot project at Kolo-Hills forests has demonstrated blueprint to failure rather than success for the forthcoming REDD+ programme.

The fact that government under JFM and CBFM approaches has room to question and sue the community in case of failure to implement forest management as per the management plan approved by the government while the community do not have such room in case of government failure to meet its roles seems to oppose the idea of power sharing and instead reveals inequitable accountability. This can be witnessed where Forest Act gives mandate to the Director of Forestry or local governments to take over the management of forests that are under JFM or CBFM when the forests under PFM are deemed to be mismanaged (Forest Act 2002, s. 8 and 41-48). In contrast for about 20 years of PFM implementation the government have failed to formalize benefit sharing mechanism especially on productive forests managed under JFM regime [44]. While the JFM regime is aimed at cutting off management costs from government on already gazetted government forest reserves, the underlying policy goal for CBFM is to bring large areas of unprotected woodlands and forests progressively under village management and protection through establishment of VLRFs [20, 27]. Accordingly the silence restriction on harvesting of timber products from the ever known best CBFM success sites including Angai forests and SULEDO as noted in study by Mustalahti and Lund [45] gives no doubt that all what has been done to convince communities to adopt PFM as winwin approach might be elusive. Under such skewed power relationships, power struggle instead of power sharing, and competition instead of collaboration between community and government, one can view PFM as a strategy for the government through its forest agencies to deliberately use power to burden the poor and marginalized rural citizens with conservation costs. This has been through exploitation of their energy, time, and resources to meet conservation interests under PFM with no clear terms on benefit sharing.

Effective PFM implementation necessitates a firm commitment on shifting from competitive psychological orientation which permits inequality and emphasizes a winlose struggle for superiority and instead orients towards a cooperative psychological orientation which emphasizes equal powers and win-win mutual relations. Among benefits of power sharing according to [30] are an increase in decision acceptance, commitment, and quality and enhanced satisfaction and commitment. Hence by unification of interests and balancing power among stakeholders PFM is likely to achieve its multiple integrated objectives.

\section{Conclusion and Recommendation}

From the findings we concluded that where PFM approaches are adopted on papers while decisive power is retained by central government the outcomes have been an accelerated degradation of resources instead of improved conservation. The large part of PFM processes involved power relations that are contrary to power sharing. Both the government and local communities have been exercising power struggle in fulfilling their interests over the forest resources. This power struggle between community and government stakeholders of PFM has been transferred to REDD+ pilot project. The findings are empirical evidence that this supports our description of power relations exercised under PFM as an obstacle rather than reliever to the forthcoming REDD+ programme. Unless power relation trend is reversed, practical REDD+ on PFM platform is erroneous.

To improve from the weak situation disclosed by this study, we recommend the policy makers to amend the Forest Policy, Forest Act, and legislation in order to achieve the following:

(i) Put clear terms for benefit sharing.

(ii) Fill gaps of provisions to strengthen community empowerment.

(iii) Clarify responsibility of every PFM stakeholder.

(iv) Clarify means through which every stakeholder will be accountable in the course of undertaking the responsibilities.

\section{Knowledge Contribution of the Paper}

This paper shed light on potential of power relations amongst the main stakeholders (community and the government) as determinant factor to success or failure of PFM. The findings contribute to a more informed academic and political sphere on power relations potential barrier to REDD+ programme which is existing in PFM as a framework for REDD+.

\section{Conflict of Interests}

The authors declare that there is no conflict of interests regarding the publication of this paper.

\section{Acknowledgments}

The authors are highly grateful to the Government of the Kingdom of Norway under Tanzania-Norway Climate Change Partnership Programme for financial support to this study through CCIAM research project. The authors acknowledge the entire Kondoa district staff and AWF management and communities of study villages for their tireless collaboration during data collection.

\section{References}

[1] A. Agrawal and C. C. Gibson, "Enchantment and disenchantment: the role of community in natural resource conservation," World Development, vol. 27, no. 4, pp. 629-649, 1999.

[2] S. Wiggins, K. Marfo, and V. Anchirinah, "Protecting the forest or the people? Environmental policies and livelihoods in the forest margins of Southern Ghana," World Development, vol. 32, no. 11, pp. 1939-1955, 2004.

[3] L. Tole, "Reforms from the ground up: a review of communitybased forest management in tropical developing countries," Environmental Management, vol. 45, no. 6, pp. 1312-1331, 2010. 
[4] D. Ghai and J. M. Vivian, Grassroots Environmental Action: People's Participation in Sustainable Development, Routledge, London, UK, 2014.

[5] G. C. Kajembe and G. C. Monela, "Empowering communities to manage natural resources: where does the new power lie? A case study of Duru-Haitemba, Babati, Tanzania," in Empowering Communities to Manage Natural Resources: Case Studies from Southern Africa, pp. 151-163, 2000.

[6] D. B. Raik, A. L. Wilson, and D. J. Decker, "Power in natural resources management: an application of theory," Society and Natural Resources, vol. 21, no. 8, pp. 729-739, 2008.

[7] L. A. Wily, Land Tenure Reform and the Balance of Power in Eastern and Southern Africa, Overseas Development Institute, 2000.

[8] L. A. Wily, "A review of new policy towards participatory forest management in eastern Africa," For CARE Review of Policy Towards Participatory Forest Management in Eastern Africa, 2002.

[9] M. Nuijten, "Power in practice: a force field approach to natural resource management," The Journal of Transdisciplinary Environmental Studies, vol. 4, no. 2, pp. 1-14, 2005.

[10] C. Ansell and A. Gash, "Collaborative governance in theory and practice," Journal of Public Administration Research and Theory, vol. 18, no. 4, pp. 543-571, 2008.

[11] F. Berkes, "Evolution of co-management: role of knowledge generation, bridging organizations and social learning," Journal of Environmental Management, vol. 90, no. 5, pp. 1692-1702, 2009.

[12] H. Zheng and S. Cao, "Threats to China's biodiversity caused by policy contradictions and unexpected consequences," Ambio, vol. 44, pp. 23-33, 2014.

[13] S. Cao, L. Chen, and Q. Zhu, "Remembering the ultimate goal of environmental protection: including protection of impoverished citizens in China's environmental policy," Ambio, vol. 39, no. 6, pp. 439-442, 2010.

[14] H. Vihemäki, "Participation or further exclusion? Contestations over forest conservation and control in the East Usambara Mountains, Tanzania," 2009.

[15] A. Giddens, The Constitution of Society: Outline of the Theory of Structuration, Polity Press, Cambridge, UK, 1984.

[16] F. Cleaver, "Understanding agency in collective action," Journal of Human Development, vol. 8, no. 2, pp. 223-244, 2007.

[17] S. Lukes, Power: A Radical View, Palgrave MacMillan, New York, NY, USA, 2nd edition, 2005.

[18] A. Benjaminsen Tor and H. Svarstad, Political Ecology: The Environment, People and Power, Universitetsforlaget, Oslo, Norway, 2010.

[19] M. Barnett and R. Duvall, "Power in international politics," International Organization, vol. 59, no. 1, pp. 39-75, 2005.

[20] United Republic of Tanzania, The National Forest Policy, Ministry of Natural Resources and Tourism, Forest and Beekeeping Division, Government Press, Dar es Salaam, Tanzania, 1998.

[21] United Republic of Tanzania, The New Forest Act. No. 14 of 7th June 2002, Government Printer, Dar es Salaam, Tanzania, 2002.

[22] United Republic of Tanzania (URT), The Local Authorities Act no. 7 (District and Urban Authorities), Government Printer, Dar es Salaam, Tanzania, 1982.

[23] United Republic of Tanzania, The Land Act 1999. No. 4 of 15th May 1999, Government Printer, Dar es Salaam, Tanzania, 1999.

[24] United Republic of Tanzania, The Village Land Act (No. 5 of 1999), Government Printer, Dar es Salaam, Tanzania, 1999.
[25] A. Pallotti, "Tanzania: decentralising power or spreading poverty?" Review of African Political Economy, vol. 35, no. 2, pp. 221-235, 2008.

[26] R. Bullock, Rhetoric versus reality in participatory forest management in East Usambaras, Tanzania [Doctoral dissertation], University of Florida, 2010.

[27] T. Blomley and S. Iddi, Participatory Forest Management in Tanzania: 1993-2009, Lessons Learned and Experiences to Date, Ministry of Natural Resources and Tourism, 2009.

[28] A. Agrawal and E. Ostrom, "Collective action, property rights, and decentralization in resource use in India and Nepal," Politics \& Society, vol. 29, no. 4, pp. 485-514, 2001.

[29] J. Phelps, E. L. Webb, and A. Agrawal, "Does REDD+ threaten to recentralize forest governance?" Science, vol. 328, no. 5976, pp. 312-313, 2010.

[30] I. Mustalahti, A. Bolin, E. Boyd, and J. Paavola, "Can REDD+ reconcile local priorities and needs with global mitigation benefits? Lessons from Angai Forest, Tanzania," Ecology and Society, vol. 17, no. 1, article 16, 2012.

[31] T. Blomley and H. Ramadhani, "Going to scale with participatory forest management: early lessons from Tanzania," International Forestry Review, vol. 8, no. 1, pp. 93-100, 2006.

[32] D. Brockington, "Forests, community conservation, and local government performance: the village forest reserves of Tanzania," Society and Natural Resources, vol. 20, no. 9, pp. 835-848, 2007.

[33] I. Mustalahti, Handling the stick: practices and impacts of participation in forest management [Ph.D. thesis], Danish Centre for Forest, Landscape and Planning, Faculty of Life Sciences, University of Copenhagen, Copenhagen, Denmark, 2007.

[34] H. Sjoholm and S. Luono, "Traditional pastoral communities securing green pastures through participatory forest management: a case study from Kiteto District, United Republic of Tanzania," in Proceedings of the 2nd International Conference on Participatory Forest Management in Africa, February 2002.

[35] C. A. Mwakasendo, Forest income and rural livelihoods under Suledo community based forest management in Kiteto district [Ph.D. dissertation], Sokoine University of Agriculture, 2009.

[36] MOAC, "Status and causes of land degradation in Mbulu, Kondoa and Singida districts, Tanzania and strategies for conservation and rehabilitation," Tech. Rep., Ministry of Agriculture and Co-Operatives, FAO, 1996.

[37] E. J. M. Shirima, "Benefits from dual purpose goats for crop and livestock production under small-scale peasant systems in Kondoa eroded areas, Tanzania," Livestock Research for Rural Development, vol. 17, no. 12, 2005.

[38] KDC, Kondoa District Socio-Economic Profile, Kondoa District Council, Kondoa, Tanzania, 2011.

[39] K. John, D. S. A. Silayo, and A. Vatn, "The cost of managing forest carbon under REDD+ initiatives: a case of Kolo hills forests in Kondoa District, Dodoma, Tanzania," International Journal of Forestry Research, vol. 2014, Article ID 920964, 12 pages, 2014.

[40] G. J. Casimir and H. Tobi, "Defining and using the concept of household: a systematic review," International Journal of Consumer Studies, vol. 35, no. 5, pp. 498-506, 2011.

[41] C. Frankfort-Nachmias and D. Nachmias, Research Methods in the Social Sciences, St. Martin's Press, New York, NY, USA, 5th edition, 1996.

[42] B. Cooksey, L. Anthony, J. Egoe et al., Management of Natural Resources Programme, Tanzania TAN-0092, Final Evaluation 
Report, Ministry of Natural Resources and Tourism and the Royal Norwegian Embassy, Dar es Salaam, Tanzania, 2006.

[43] J. C. Ribot, A. Agrawal, and A. M. Larson, "Recentralizing while decentralizing: how national governments reappropriate forest resources," World Development, vol. 34, no. 11, pp. 1864-1886, 2006.

[44] A. Scheba and I. Mustalahti, "Rethinking 'expert' knowledge in community forest management in Tanzania," Forest Policy and Economics, 2015.

[45] I. Mustalahti and J. F. Lund, "Where and how can participatory forest management succeed? Learning from Tanzania, Mozambique, and Laos," Society and Natural Resources, vol. 23, no. 1, pp. 31-44, 2010. 

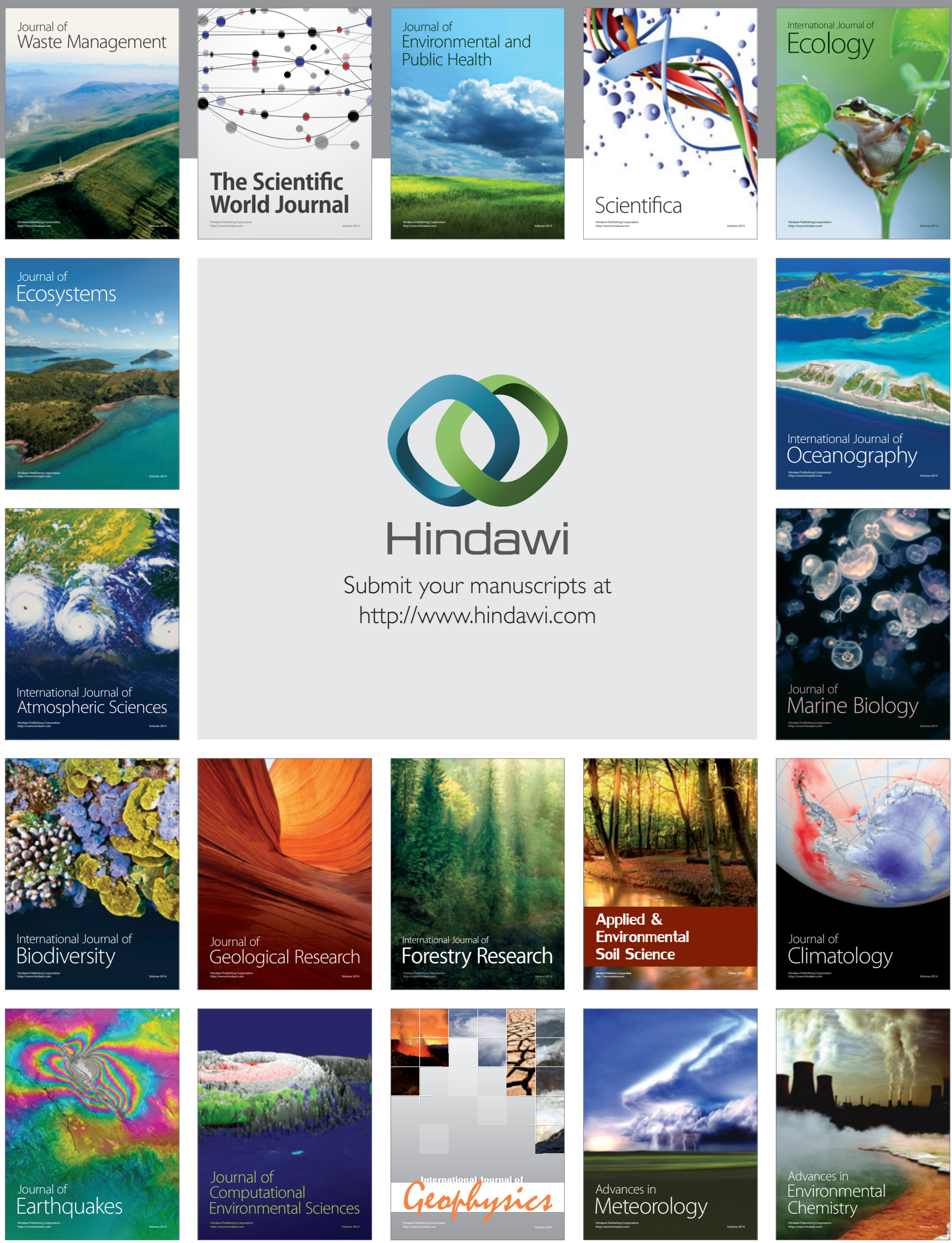